\author{
ナノトライボロジー \\ 三宅 正二郎 ${ }^{a}$ \\ ${ }^{a}$ 日本工業大学 ( ₹ 345-8501 埼玉県南埼玉郡宮代町学園台 4-1) \\ Nanotribology
}

Shojiro MIYAKE ${ }^{\text {a }}$

${ }^{a}$ Nippon Institute of Technology(4-1, Gakuendai, Miyashiro-machi, Minamisaitama-gun, Saitama 345-8501)

Keywords : Nanotribology, Microtribology, Nanoindentation, Nanowear, Magnetic Disk

\section{1. ナノトライボロジーと表面技術}

\section{1 マイクロ・ナノトライボロジー}

情報機械, 細胞, DNA 等のバイオ, 医療関係, マイクロ・ ナノマシン, マイクロ・ナノシステムなどの分野の発展とと もにその性能および信頼性を確保するため可動部の耐久性を

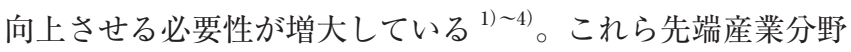
の各種機械, 装置などの高性能化, 小型化にともない微少量 の摩耗, 微小な摩擦力変動が問題になり, トライボロジー特 性に関して極表面層の重要性が増大している。例えば, 磁気 ディスク装置のヘッド・ディスクインターフェースでは荷重 が小さく, マイクロまたはナノトライボロジーと呼ばれる極 表面の摩擦現象になり, 表面の極薄層が影響を与え, 薄膜に よる潤滑が行われている ${ }^{2), 3)}$ 。磁気ディスクのヘッド・ディ スクインターフェースでは図 1 に示すように各種表面技術が 取り入れられている。現在では磁気ディスク, 磁気ヘッドそ れぞれに $5 \mathrm{~nm}$ 以下のカーボン保護膜が形成され, さらに $1 \mathrm{~nm}$ 程度のフッ素系潤滑膜により耐久性が確保されている。 記録密度を向上させるため浮上隙間が小さくなり, $1 \mathrm{~nm}$ 程 度の極薄保護膜が検討されている。さらに記録の信頼性を向 上するため, 高保磁力磁性媒体を用い記録時にレーザ光など で加熱する熱アシスト法の研究開発が進められている。

摩擦・摩耗・潤滑に関する表面近傍での諸現象を微視的に 取り扱う科学技術分野がマイクロまたはナノトライボロジー と呼ばれる。マイクロスコピックに見れば摩擦は相対する表

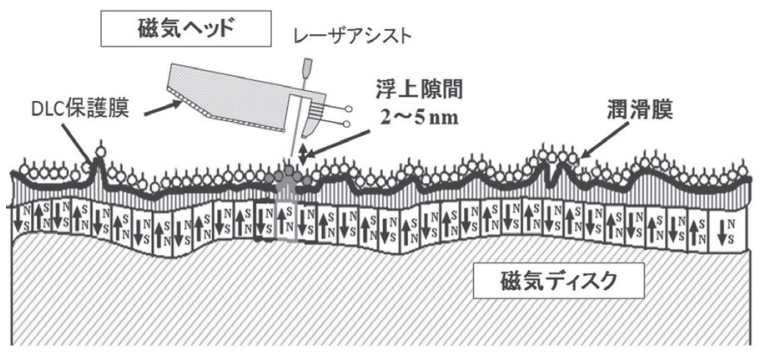

図1磁気ディスクのヘッド・ディスクインターフェース
面の各原子間の相互作用に, 摩耗は表面原子の結合と破壊に なる。しかし, 従来のトライボロジーでは, このような物質 の粒子性を無視し，均質な連続体モデルとして扱ってきた。 これに対し, 例えば, 情報機器の摩耗では何回かの摩擦回数 に対して, 1 パス当たりの平均的な摩耗深さが 1 原子層以下 になることが要求されている。原子は最小でも 1 個単位でし か摩耗しないから従来の比摩耗量という連続的な概念ではな く, 原子単位の不連続な摩耗が生じる ${ }^{1), 5)}$ 。当初, これらは マイクロトライボロジーと呼ばれていたが, 現象を $\mathrm{nm}$ ス ケールで観察, 評価する場合が多くなり, ナノトライボロジー と呼ばれることが多くなっている。ここではナノトライボロ ジーと呼ぶ。

\section{2 摩擦・摩耗を低減するための表面技術}

摩擦力を低減するための表面材料構成としては硬質材料に せん断抵抗の小さい軟質薄膜を形成する方法が広く知られて いる。硬質材料が荷重を分担し, 軟質薄膜でせん断が生じ る $^{1), 6)}$ このモデルでさらに摩擦を減少するためには構成材 料の硬さ, 弾性係数を増大し, 接触面積を減少させ, かつ表 面のせん断抵抗を低減すれば良い。したがって摩擦構成材料 として硬質材料を用い, 適切な潤滑剂の供給または表面材料 構成を行い, 接触部のせん断抵抗を減少させることにより低

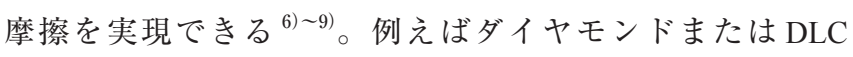
(Diamond-like carbon) 膜は高硬度であるうえさらに低摩擦で あり, 無潤滑下で摩擦係数 $\mu=0.1$ 程度が比較的容易に得ら れる。さらに表面をフッ素プラズマで処理すれば摩擦を低減 することができる ${ }^{7)}$ 。ダイヤモンド, DLC 膜の摩擦係数は 低荷重領域で吸着層の影響を受け上昇傾向を示すが, フッ素 処理により表面エネルギーを小さくでき, 安定して低摩擦を 示す ${ }^{7), 9)}$ 。

ナノトライボロジーでは原子オーダの摩耗が問題となり, 使用期間中の摩耗を原子層以下に低減すること, すなわち実 用観点からゼロ摩耗を実現することが必要になっている。原 子オーダの摩耗を低減するための表面材料構成として摩擦特 性, 耐久性に優れる超硬質膜を主成分とし, 表面改質により 低エネルギー化させた表面が期待される ${ }^{6), 9) 。 ~}$ 
ダイヤモンドは最も硬い材料でありアブレッシブ, 凝着摩 耗などに対して優れた耐摩耗性を示す。ダイヤモンドチップ とのナノ摩耗試験では, 未注入ダイヤモンドは原子スケール で摩耗は観察されない。ダイヤモンド膜に窒素イオンを注入 するとナノ摩耗が増大する。しかしマクロ的な摩擦耐久性は 向上する。これは窒素注入によってダイヤモンド構造が崩れ， アモルファス化しており，硬度が減少したと考えられる ${ }^{8)}$ 。 また，ダイヤモンドのフッ素処理は処理層が浅く，摩耗は観 察されない。このように超硬質膜を用いた表面構造設計によ り $\mathrm{nm}$ スケールのゼロ摩耗が実現できる。

\section{2. ナノトライボロジー特性の評価と DLC 膜の測定例}

ナノトライボロジーの特性を評価するために SPM (Scanning probe microscopy) 技術が活用されている ${ }^{10)}$ 。例え ばプローブにより微小な原子間力を測定する AFM (Atomic force microscopy), 摩擦力を検出する FFM (Friction force microscopy) を用いれば, 微小荷重の摩擦, 摩耗特性などナ

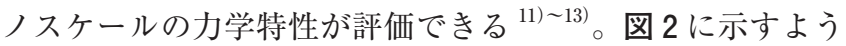
にフォースモジュレーションは力変調モードで, 縦方向と横 方向の振動がある ${ }^{12)}$ 。AFMのフォースモジュレーション法 を応用し, 振動摩耗試験および表面の摩擦力, 粘弾性, ダイ ナミックスの評価が可能になる。次に DLC 膜のナノトライ ボロジー特性を評価した結果を述べる。

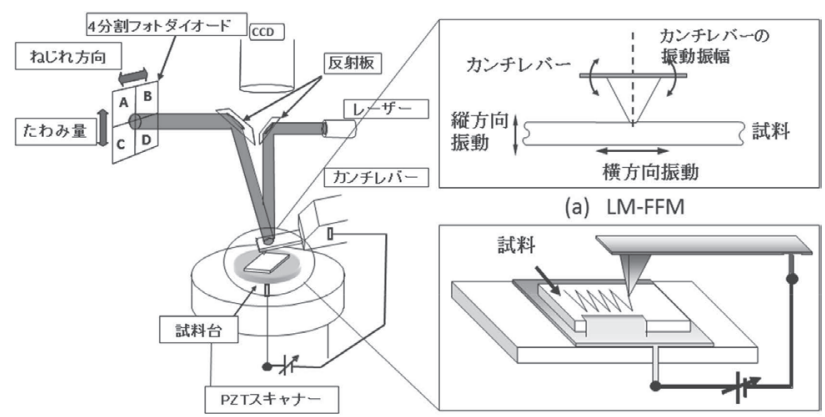

(b) 横振動摩耗試験

図2 原子間力顕微鏡におけるフォースモジュレーション

\section{1 ナノインデンテーション試験}

表面の力学的物性を的確に評価するために, 表面の強度の 目安となり測定が比較的容易であるという理由で硬さの評価 が広く行われている。薄膜の硬さ測定として高硬度材料を押 しつけて生じる変形を調べる押し込み硬さが主に用いられる。 極表面の評価では押し込み荷重が大きいと表面層を貫通する など下地の影響を受けやすい。このため, 従来の微小硬さ試 験法では評価できなくなっており，いわゆる AFM を活用し たナノインデンテーション試験が適用されている。ナノイン デンテーション試験では, 圧電素子を用いて, ダイヤモンド 圧子に $\mathrm{nN} \sim \mathrm{mN}$ レベルの微小荷重 $\mathrm{W}$ を加え, 試験片への 侵入量 $\mathrm{h}$ を変位センサーで測定し, 最表面層や極薄膜の力学 的特性を評価する。ナノインデンテーションカーブの測定例 として FCVA (Filtered Cathodic Vacuum Arc) 法で形成した DLC 膜の直流バイアス電圧依存性を図 3 (a)に示す ${ }^{13)}$ 。硬さ $\mathrm{H}$ は W/Ar (荷重/接触断面積) から, ヤング率 $\mathrm{E}$ は除荷カー ブの接線の傾きから求められる。さらに材料の塑性変形の容 易さを示す塑性指数の材料定数 $\mathrm{E} / \mathrm{H}$ が求められる ${ }^{13)}$ 。変形 エネルギー解析も有効であり負荷曲線を積分することにより 全エネルギー $\left(\mathrm{S}_{1}+\mathrm{S}_{2}\right)$ を求め, 除荷曲線を積分することに より貯蔵エネルギー $\left(\mathrm{S}_{2}\right)$ を求める。全エネルギーから貯蔵エ ネルギーを引くことによって散逸エネルギー $\left(\mathrm{S}_{1}\right)$ が求まる。 さらに散逸エネルギーを全変形エネルギーで除して, 散逸率 $\left(\mathrm{S}_{1} /\left(\mathrm{S}_{1}+\mathrm{S}_{2}\right) \times 100 \%\right)$ が算出される。図 $3(\mathrm{~b})$ に示すように 硬さ増大に対して散逸率, $\mathrm{E} / \mathrm{H}$ は減少し, 塑性変形し難いこ とを示している。散逸率, $\mathrm{E} / \mathrm{H}$ と硬さの関係には, 回帰分析 で高い逆の相関が得られる ${ }^{14)}$ 。通常の材料の $\mathrm{E} / \mathrm{H}$ は $14 〜 20$ 程度の值 ${ }^{1)}$ が知られており, これに対し, 適切な条件で形成 した DLC 膜では $\mathrm{E} / \mathrm{H}=7$ と小さく, ナノインデンテーショ ン試験の解析から FCVA-DLC 膜の優れた耐塑性変形特性が 理解される。

\section{2 ナノ摩耗試験}

薄膜自体の硬さを測定する際は，下地の影響を避けるため， 極低荷重で試験する。この時，表面の状態によっては誤差が 入り易いので平均化するため四角形状のナノ摩耗試験が行わ

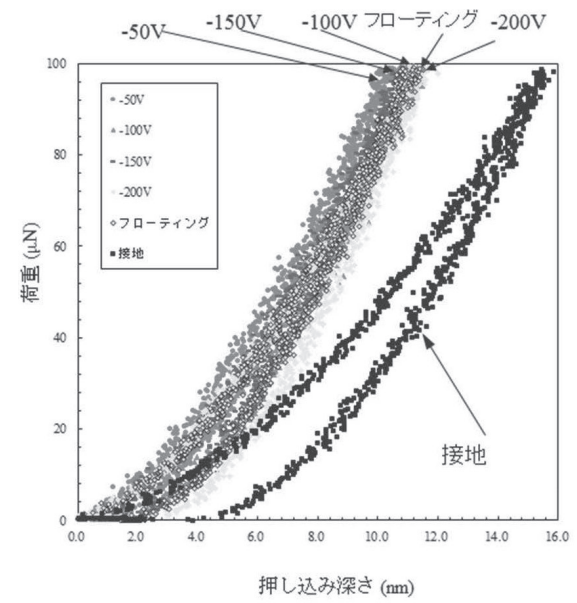

(a) ナノインデンテーションカーブ

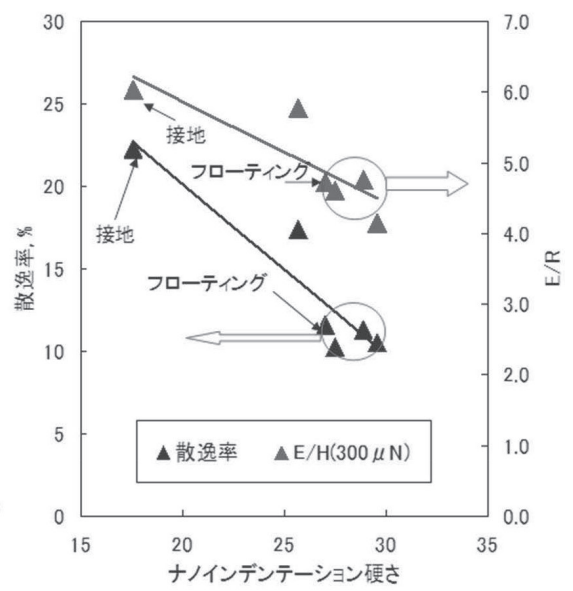

(b)塑性変形定数の関係

図 3 ナノインデンテーション試験結果の膜形成時 DC バイアス電圧依存性 
れている ${ }^{3), 15)}$ 。例えば窒素含有カーボン $(\mathrm{C}-\mathrm{N})$ のナノ摩耗特 性が AFM を用い評価されている ${ }^{15)}$ 。膜の形成条件により表 面あらさが変化するのでナノインデンテーション硬さは変動 し，信頼性のある評価が困難であったのに対し，正方形状の ナノ摩耗試験により窒素含有の効果が明らかにされている。 $\mathrm{C}-\mathrm{N}$ 膜の摩耗深さは C 膜の約 1/10 程度となり, 原子オーダ のナノ摩耗で明確な差が評価できている。

図 4 は, FCVA-DLC 膜の膜形成時のバイアス電圧を変化 させた時のナノ摩耗特性を示している。原子オーダの摩耗深 さを評価するため, 摩耗痕の近くの形状高さのヒストグラム を求めた。図 4 (d) に示す様にそれぞれの DLC 膜について,

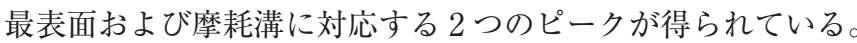

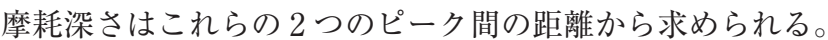

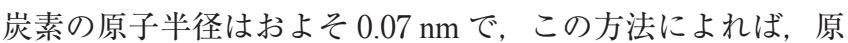
子に対応する摩耗深さが評価できる。また，DC - 50V で形 成した DLC 膜については, 摩耗溝は平滑で, ピーク間の差 $0.6 \mathrm{~nm}$ が評価できている, 接地で形成した DLC 膜は表面粗 さが大きいが，摩耗痕底面のピークは最表面から区別でき摩 耗深さは約 $2.5 \mathrm{~nm}$ である。パルスバイアス電圧で形成した 膜の摩耗深さは，1.8 nm で， DCバイアス電圧で形成した膜

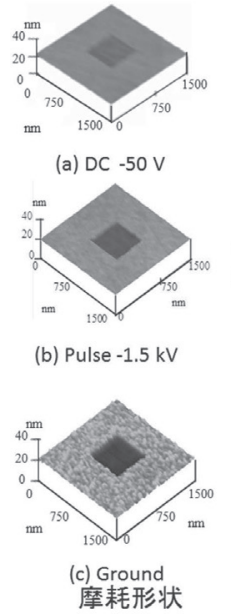

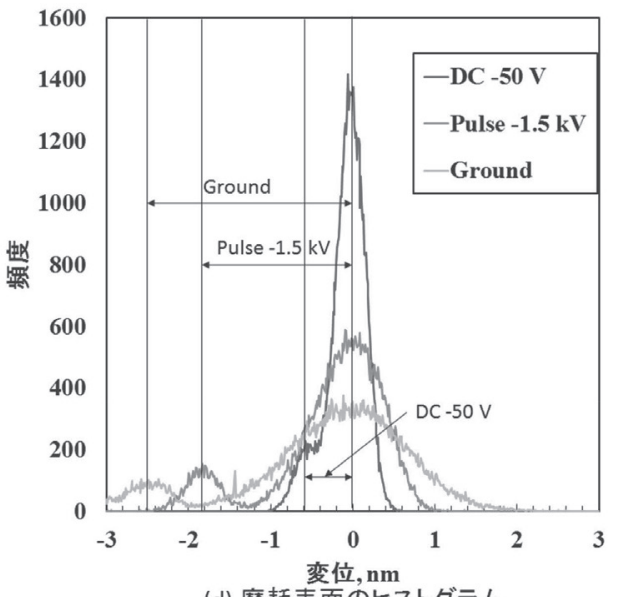

(d) 摩耗表面のヒストグラム
より深い。異なるバイアス電圧で形成したDLC 膜の摩耗深 さとナノインデンテーション硬さの散布図では, 強い逆相関 が見られ, その, 相関係数 $\mathrm{R}=0.87$ が得られている ${ }^{14)}$ 。こ のようにナノインデンテーション, ナノ摩耗試験により,

$4 \mathrm{~nm}$ 以下の極表層でも形成法によるナノトライボロジー特 性の差を評価できる。これらの結果はラマンで評価したナノ 構造と対応しており，膜形成条件にフィードバックできる。

\section{3. 極薄 DLC 膜のナノトライボロジー}

磁気ディスク保護膜では高記録密度化するため $1 \mathrm{~nm}$ 程度 の極薄膜化が要求されている。FCVA および CVD (Chemical vapor deposition) 法によって形成した極薄 DLC 膜のナノトラ イボロジー特性を評価した例を紹介する ${ }^{16)}$ 。

ナノスクラッチ試験は硬い圧子で薄膜を引っかいて摩擦力 や摩擦痕の形状などを計測し, 表面のスクラッチ硬さやせん 断強さ，あるいは薄膜の付着強さなどを調べるものである ${ }^{1)}$ 図 5 に極薄 DLC 膜のナノスクラッチ特性を示す ${ }^{17)}$ 。FCVADLC, CVD-DLC 膜ともにスクラッチ深さが膜厚付近に達し た後, 深くなっている。特にFCVA-DLC 膜では膜厚到達後 の破壊が CVD-DLC 膜に対して大きく，原子数個分の DLC 膜でも膜形成法による特性の変化が現れている。膜形成法な

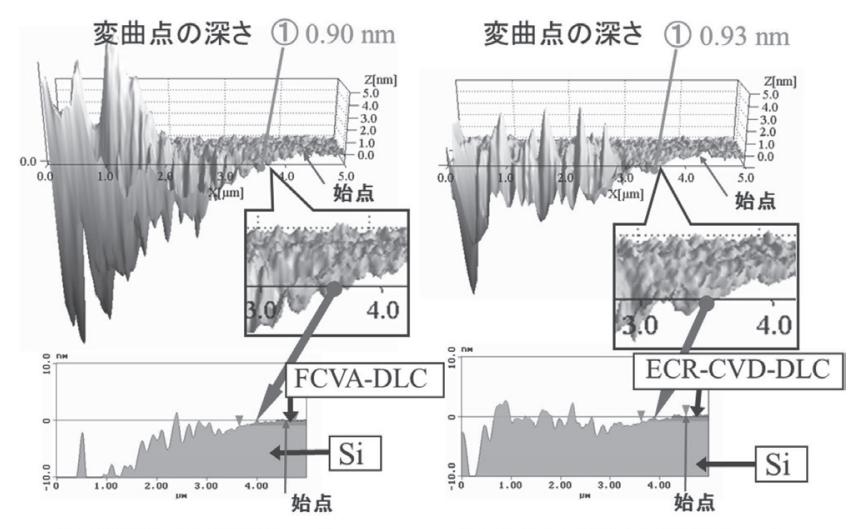

(a) FCVA-DLC $(0.8 \mathrm{~nm})$

(b) ECR-CVD-DLC $(0.8 \mathrm{~nm})$

図 4 ナノ摩耗深さの膜形成条件依存性

図 5 極薄 DLC 膜のナノスクラッチ特性
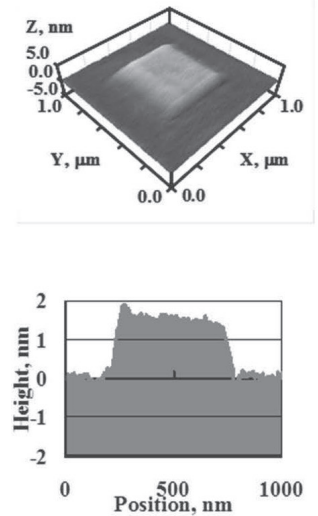

摩擦による隆起
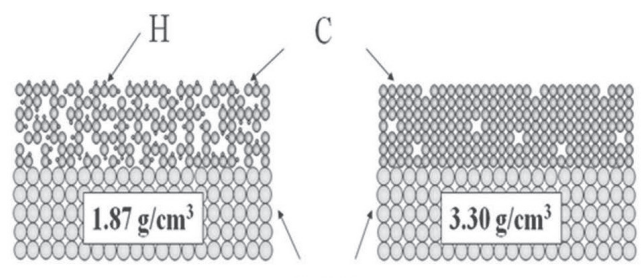

$\operatorname{Si}(100)$

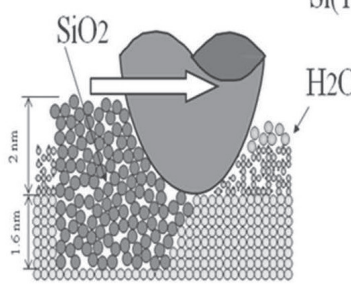

(a) ECR-CVD-DLC 1.0-nm

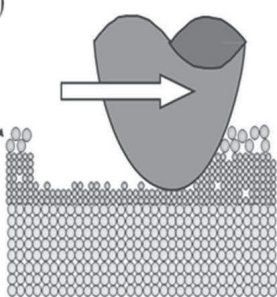

(b) FCVA-DLC 1.0-nm

図 6 極薄 DLC 膜のナノ摩耗における隆起とそのメカニズム 
どから詳細に検討すると FCVA は硬く，優れた耐塑性変形性 特性を示すが, 一度破壊が生じるとその単位は大きく, 下地 も含め急激に変形する。すなわち脆性破壊し易いことを示し ている。

FCVA と CVD 法で形成した $1 \mathrm{~nm}$ 程度の DLC 膜のナノ摩 耗試験結果を図 6 に示す ${ }^{18)}$ 。CVD-DLC 膜では $1 〜 2 \mathrm{~nm}$ 程 度の隆起が生じている。これに対して FCVA-DLC 膜では摩 耗が生じている。CVD-DLC 膜では摩擦作用により, 下地の $\mathrm{Si}$ とのトライボケミカル反応によるシリコン酸化物形成お よび損傷を含む構造変化を引き起こし，その結果，隆起する。 ナノ摩耗試験後, トライボケミカル反応により, 均一な $\mathrm{SiO}_{2}$ 層が形成されるとすれば, $1.6 \mathrm{~nm}$ 厚さの $\mathrm{Si}$ 層が, トラ イボケミカル反応により $3.6 \mathrm{~nm}$ 厚の $\mathrm{SiO}_{2}$ に変化したことに なる。トライボケミカルな反応層には, $\mathrm{SiO}$ やダメジが含ま れており，実際に反応する $\mathrm{Si}$ は $1.6 \mathrm{~nm}$ より深いと思われる。 対照的に, FCVA-DLC 膜の摩耗深さは, 図6 (b)に示すように, ほぼ $0.7 \mathrm{~nm}$ であり, ダイヤモンドチップは, Si 基板に到達 していない。 $\mathrm{Si}$ 基板のトライボケミカル反応が残留 FCVADLC 膜により阻止されたと考えられる。これらはFCVADLC 膜の高い密度 $\left(3.3 \mathrm{~g} / \mathrm{cm}^{3}\right)$ によるものと考えられる。

高記録密度化のため開発が進められている熱アシスト法の ナノトライボロジー特性への影響を明らかにするため, 高温 でのナノトライボロジー特性を, 環境制御型原子間力顕微鏡 を用いて評価した。図 7 に極薄 DLC 膜の高温中のナノ摩耗 特性を示す ${ }^{19)}$ 。室温(RT)で, FCVA-DLC 膜は, CVD-DLC 膜 よりも優れた耐摩耗性を示す。逆に, 高温真空中では FCVADLC 膜の摩耗が急増した。摩擦力は, 室温で低いが, 高温 真空中で非常に高い。これは表面の吸着物が, 高温での摩擦 で除去され，FCVA-DLC膜の破壊が生じ，硬くて脆い摩耗 粉がアブレッシブとして作用し，摩耗を増加させている。こ れに対して CVD-DLC 膜は高温で低摩擦を示す。これは, 潤 滑性のトライボケミカル生成物が形成され ${ }^{20)}$, 摩擦を低減し, 摩耗が少なくなったと考えられる。

\section{4. 磁気ディスク潤滑膜のナノトライボロジー}

磁気デイスク装置の信頼性を確保するには表面に形成する 潤滑層のナノトライボロジー特性の改善が重要である。その
ため, ディスク表面の潤滑膜の挙動を明らかにする必要があ る。横方向振動摩擦試験が行われ, 膜厚 $1 \mathrm{~nm}$ 程度の潤滑層 による表面破壊防止効果, 潤滑油の補給効果など特に単分子 層からなる PFPE (perfluoropolyether) 潤滑油の摩擦時の挙動 を明らかにする必要がある ${ }^{21,22) 。 ~}$

垂直磁気ディスク DLC 保護膜上の潤滑油の挙動を調べる ために，図 2 に示すように縦，横方向振動を付加した振動摩 耗試験が行われている。さらに試験後の横および縦方向に振 動させるフォースモジュレーション特性から, 摩擦部の摩擦 力, 粘弾性などが評価されている。フォースモジュレーショ ンで測定した垂直磁気デイスクの表面形状と位相を図 8 (a) (b)に示す ${ }^{22)}$ 。表面に磁性層の結晶粒が観察されている。ま た位相は結晶粒の溝部に対応するところで増大し, 溝部に多 く潤滑油が存在していることが分かる。摩耗試験では振動付 加により摩耗深さは増大し, 特に横方向振動を付加した場合 の摩耗媣さが最も大きい。また摩擦部の摩擦力分布は図 8(c), （d）に示す様に未処理の場合，すべての試験部の摩擦力が減 少している ${ }^{22)}$ 。一方，熱キュアした場合には試験部の摩擦 力が増大している。特に横方向振動を付加した場合の摩擦力 の増加が著しい。さらに摩擦試験部の縦方向のフォースモ ジュレーションで粘弾性分布を求めると潤滑油の存在量が評

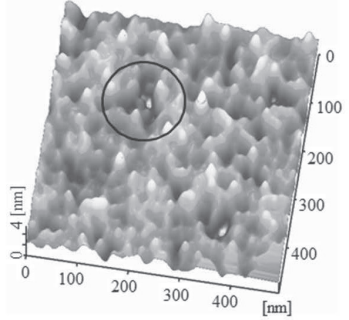

(a) 表面形状

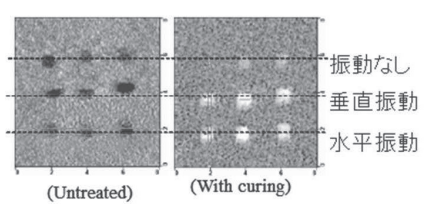

(c) 摩擦力分布

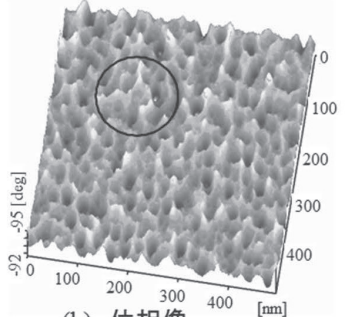

(b) 位相像

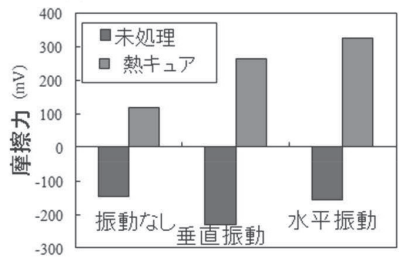

(d) 摩擦力の変化
図 8 磁気ディスク潤滑膜の振動摩耗特性
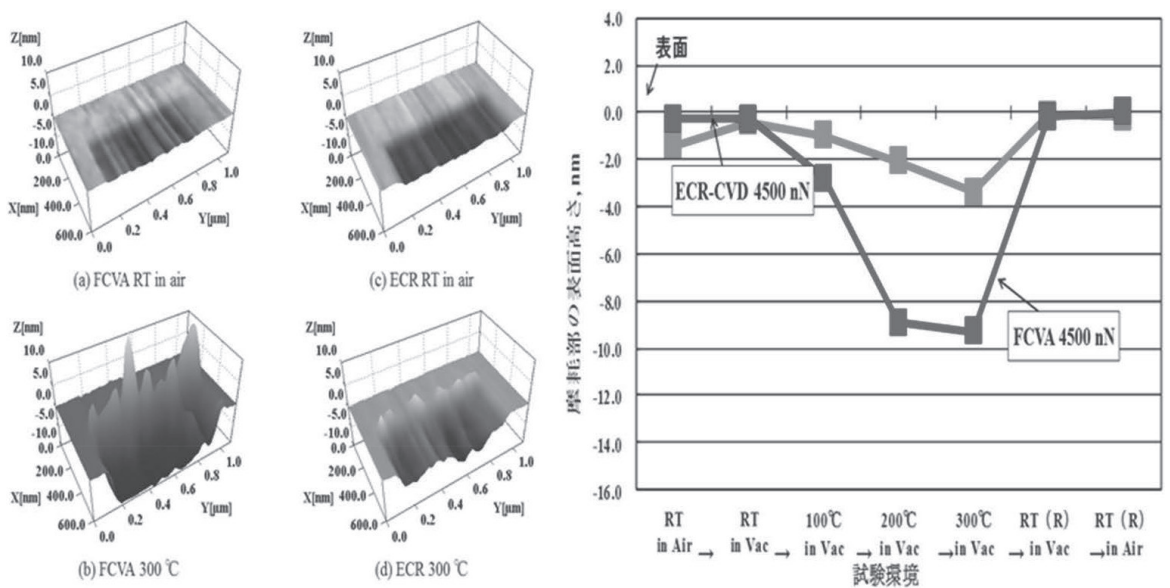

図 7 極薄 DLC 膜の高温中のナノ摩耗特性 

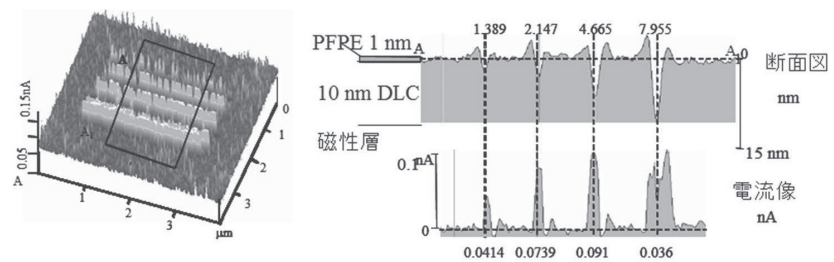

(a) UVキュア
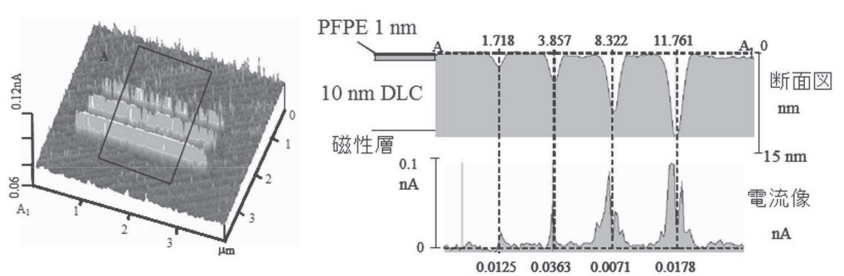

(b) 未処理

図 9 磁気ディスク潤滑油挙動におけるキュア処理の効果

価でき，未処理の場合には摩擦によって潤滑油が補給された ことを示している。これに対して，熱キュアした場合は摩擦 試験部の粘弾性が減少し, 熱キュアによって硬化した潤滑油 が横振動摩擦で除去されていることを示している。このよう に未処理の潤滑油では磁気ディスク表面の結晶粒溝部からの 潤滑油補給効果を確認できている ${ }^{23)}$ 。

表面の損傷, 潤滑油の状態などの特性を評価するためには 力学特性と他の物性值を同時に評価するのも有効である。例 えば磁気ディスク潤滑油の紫外線(UV) キュア処理の効果を 明らかにするためフォースモジュレーションの横方向振動摩 耗試験を行い, 表面の損傷状態および潤滑油の状態が摩擦力 と電流分布から評価されている。図 9 に示すようにUV 処理 した場合, 摩耗溝周辺に潤滑油の盛り上がりが見られるのに 対し，未処理では流動性があるので溝部中心に潤滑油が流入 し, 電流值が減少している。このように潤滑油の特性に基づ く $\mathrm{nm}$ スケールの挙動が観察されている ${ }^{24)}$

\section{5.おわりに}

磁気ディスク装置, AFMメモリー ${ }^{25)}$, ナノファブリケー ション ${ }^{26)}$ などナノテクノロジーが進展し, 機械の寸法が小 さくなるにつれ, 表面の重要性が増大し, ナノトライボロジー に関する技術開発が必要になっている。これらの研究開発に 関する今後の発展が期待される。磁気デイスク関係の研究に ついては情報ストレージ研究推進機構 (SRC)の助成を受けた。

(Received October 1, 2014)

\section{文献}

1 ) 榎本祐嗣, 三宅正二郎; 薄膜トライボロジー(東京大学出版会, 1994).

2 ) S. Miyake, M. Wang ; Encyclopedia of Nanoscience and Nanotechnology edited by H. S. Nalwa: 19, p.399 (American Scientific Publishers, 2011).

3 ) R. Kaneko, S. Oguchi, T. Miyamoto, Y. Andoh, S. Miyake ; STLE Pub., SP-27, 31 (1990)

4 ) 森 誠之, 三宅正二郎編 ; トライボロジーの新展開と応用 (CMC 出版, 2007).

5 ) S. Miyake, R. Kaneko ; Thin Solid Films, 212, 256 (1992).

6 ）三宅正二郎; 表面技術, 51, 390 (2000).

7 ) S. Miyake; Appl. Phys. Lett., 65, (9), 1109 (1994).

$8)$ S. Miyake, R. Kaneko, T. Miyamoto ; Nuclear Inst. and Methods in Physics Research B, 108, 70 (1996).

9 ) S. Miyake, R. Kaneko, Y. Kikuya, I. Sugimoto ; Trans. ASME J. Tribol., 113, 384 (1991).

10) S. Miyake, M. Wang ; Microscopy: Science, Technology edited by A. Méndez-Vilas and J. Díaz, p.2013 (Formatex Research Center, 2010).

11）三宅正二郎 ; セラミックス, 48, 9 (2013).

12) S. Miyake, M. Wang; Atomic force microscopy/Book edited by Vijay Nalladega, 2, p.1 (InTech, 2013).

13）三宅正二郎, 斉藤喬士, 余可清, 三上隆司, 緒方 潔; 表面技術, 55,669 (2004)

14) S. Miyake, T. Shindo, M. Miyake ; J. of Nanomaterials, 2014, 1 (2014).

15) S. Miyake, S. Watanabe, H. Miyazawa, M. Murakawa, R. Kaneko, T. Miyamoto ; Appl. Phys. Lett., 65, (9), 3206 (1994).

16) S. Miyake, M. Wang ; Microscopy: advances in scientific research and education, edited by A. Méndez-Vilas, p.974 (Formatex Research Center, 2014).

17) S. Miyake, S. Yamazaki ; Wear, 305, 69 (2013).

18) S. Miyake, S. Yamazaki ; Wear, 318, 135 (2014).

19) S. Miyake, S. Kawasaki, S. Yamazaki ; Wear, 300, 189 (2013).

20) S. Miyake; Surf. and Coat. Technol., 54/55, 563 (1993).

21) S. Miyake, Y. Takahashi, M. Wang, T. Saito ; J. Phys. D: Appl. Phys., 38,2244 (2005).

22) S. Miyake, M. Wang, S. Matsunuma ; Jpn. J. Appl. Phys. 44, 5A, 3209 (2005).

23) S. Miyake, M. Wang, S. Ninomiya ; Surf. and Coat. Technol., 200, 6137 (2006).

24) S. Miyake, S. Ninomiya, M. Wang ; Jpn. J. Appl. Phys., 44, (9), L299 (2005).

25）三宅正二郎; 表面技術, 55, 858 (2004).

26) S. Miyake, M. Wang ; Vistas in Nanofabrication edited by Faiz Rahman, 9, p.175 (Pan Stanford Pub., 2012). 